\title{
Histology and Scanning Electron Microscopy of the Lower Respiratory Tract in the Adult Red Fox (Vulpes vulpes)
}

\author{
Histología y Microscopía Electrónica de Barrido de las Vías \\ Respiratorias Inferiores en el Zorro Rojo Adulto (Vulpes vulpes)
}

Eid A. Moussa* \& Said A. Hassan*

MOUSSA, E. A. \& HASSAN, S. A. Histology and scanning electron microscopy of the lower respiratory tract in the adult red fox (Vulpes vulpes). Int. J. Morphol., 33(1):267-274, 2015.

SUMMARY: The study was conducted on a total of three adult healthy freshly killed red foxes of both sexes weighing about 4$6 \mathrm{~kg}$ collected from Abou Rawwash, Giza, Egypt. The wall of trachea and bronchi formed of mucosa, submucosa and adventitia. The mucosa formed of pseudostratified columnar epithelium and lamina propria. The respiratory epithelium composed of tall columnar ciliated, goblet cells, basal cells, and neuroendocrine cells. Goblet cells account for about 20 to $30 \%$ of cells in the more proximal. Basal cells are relatively small triangular cells whose bases are attached to the basement membrane. The primary bronchiole is lined by simple columnar nonciliated to cuboidal epithelium containing some bronchiolar exocrine cells and some goblet cells. Neuroendocrine cells constitute about 4 to $5 \%$ of bronchial epithelial cells, attached at their bases to the basement membrane and have tapering apices. The lamina propria consists principally of a network of capillaries, a meshwork of connective tissue fibers continuous with the basement membrane. The submucosa formed of connective tissue elements and blood vessels and devoid of Tracheobronchial glands in red fox. The adventitia contain tracheal cartilage and muscle in trachea and bronchial cartilages and muscles in bronchi. Tracheal muscle is transverse bundles attached to the outer perichondrium. In the bronchi, muscle is organized in transverse bundles close to the epithelium adjacent to the lamina propria and longitudinal bundles close to the cartilages. Alveoli are demarcated by septa composed of a continuous layer of epithelial cells overlying a thin interstitium. The epithelial cells consist principally of type I and type II pneumocytes. SEM revealed that, the mucosal surface of both trachea and bronchi was completely covered by cilia. There were few glandular openings or goblet cell.

KEY WORDS: Scanning; Fox; Respiratory; Histology.

\section{INTRODUCTION}

The Red Fox (Vulpes vulpes) is the most widely distributed carnivore in the world and the most abundant carnivore in Egypt and is considered one of the most adaptable mammals, being able to survive in a variety of habitats ranging from the arctic areas, to the barren temperate deserts, and the densely populated cities (Basuony et al., 2005). Foxes are omnivores mostly eat invertebrates and small mammals, reptiles (such as snakes), amphibians, scorpions, grasses, berries, fruit, fish, birds, eggs, dung beetles, insects and all other kinds of small animals (Fedriani et al., 2000). The latter author added that, many species are generalist predators, but some (such as the crab-eating fox) are more particular. Most species of fox generally consume around $1 \mathrm{~kg}$ of food every day. There is no available information about the anatomy of red fox especially the histology of the respiratory tract. Therefore, this study gives adequate information about the light microscopic structure and the surface ultrastructure of the lower respiratory tract in the adult red fox (Vulpes vulpes).

\section{MATERIAL AND METHOD}

Animals. Four adult healthy red foxes weighing about 4-6 $\mathrm{kg}$ of both sexes collected from hunters at Abou Rawwash region at Giza governorate, Egypt. This study was approved by the University Institutional Animal Use oversight committee and all animal use protocols used in this study were in accordance with the National Institutes of Health Guide for the Care and Use of Laboratory Animals (National Institutes of Health, 1996). The animals were euthanized by Intravenous (IV) injection of 20\% Pentobarbitone solution in the cephalic vein (Reilly, 1993). The animals then decapitated.

Histology. For the histological study, fragments of about $1 \mathrm{~cm}$ in each length and breadth from the trachea, principle bronchus and lung were immersed in $10 \%$ formalin for $24 \mathrm{~h}$ and later submitted to the dehydration process with alcohol. Histological sections of $5 \mu \mathrm{m}$ of thickness were obtained and they were stained routinely with H\&E, periodic acid- 
Schiff (PAS) and Masson's trichrome stain. The sections were documented in Olympus microscope, model BX50, analyzed and described according to the ordinary histological technique mentioned in Dellmann \& Eurell (1998).

Scanning electromicroscopy: parts about $0.5 \mathrm{~cm}$ in each length and breadth from the trachea, principle bronchus and lung were taken and put it in fixative (glutaraldehyde paraformaldehyde buffer (1\% paraformaldehyde and $1.5 \%$ glutaraldehyde in $0.1 \mathrm{M}$ phosphate buffer, $\mathrm{PH}$ 7.2) for $2 \mathrm{~h}$ at $4{ }^{\circ} \mathrm{C}$. These parts were cut into small pieces. The pieces were washed with the same buffer then put in $0.1 \%$ osmium tetraoxide in the same buffer for $2 \mathrm{~h}$. the specimens were then dehydrated in graded series of ethanol followed by critical-point drying carbon dioxide. The specimens then sputter-coated with gold before being examined by a JEOL5400 LV scanning electron microscope.

Nomenclature. The anatomical Nomenclature used in the work was adopted according to the Nomina Anatomica Veterinaria (International Committee of Veterinary Gross Anatomical Nomenclature 2012) whenever possible.

\section{RESULTS AND DISCUSSION}

Light Microscopy (LM). The wall of trachea and bronchi formed of mucosa, submucosa and adventitia (Figs. 1 and 2 ). The mucosa formed of pseudostratified columnar epithelium (respiratory epithelium) and lamina propria. The respiratory epithelium composed of tall columnar ciliated, goblet cells, basal cells, and neuroendocrine cells (Figs. 1 and 2). In rat (Blenkinsopp, 1967), also identified these four clearly recognizable superficial cell types. In this connection (Gartner \& Hiatt, 2007), in human stated another two types called the brush and serous cells but we did not observe any of them, it might be due to the dense cilia covered the luminal surface of the respiratory epithelium. Ciliated cells are about five times more numerous than goblet cells in the central airways, and the ratio is even greater peripherally. They have thin, tapering bases that are attached firmly to the underlying basal lamina. Goblet cells account for about 20 to $30 \%$ of cells in the more proximal airways and decrease in number distally, so that only occasional cells are present in normal membranous bronchioles (Figs. 1, 2 and 3). Basal cells are relatively small, somewhat triangular cells whose bases are attached to the basement membrane and whose apices normally do not reach the airway lumen. They are more abundant in the proximal airways, where they form a more or less continuous layer, and gradually diminish in number distally, so that they are difficult to identify in bronchioles (Figs. 1, 2 and 3). Their function as a reserve from which the epithelium is repopulated, both normally and after airway injury, and are involved in the attachment of columnar epithelial cells to the basement membrane. These results were in a line with that of Alexander et al. (1971) and Corkmack \& Ham (1981) in human.

The primary bronchiole lined by simple columnar nonciliated to cuboidal epithelium containing some exocrine bronchiolar cells and some goblet cells (Fig. 3). In this field, Corkmack \& Ham stated that the primary bronchiole in human lined with ciliated columnar epithelium. The human nonciliated exocrine bronchiolar cells (Clara cells) are found primarily in membranous bronchioles. They are columnar or cuboidal in shape and bulge somewhat into the airway lumen (dome shaped apices), slightly projecting above the surrounding ciliated cells (Fraser, 2005). Moreover, exocrine bronchiolar cells secret surfactant like material keep the patency of the bronchiole and exocrine bronchiolar cell also regenerate the bronchiolar epithelium (Fraser; Fawcett, 1994) in humans, this study recorded that the Neuroendocrine cells constitute about 4 to $5 \%$ of bronchial epithelial cells and. They are attached at their bases to the basement membrane and have tapering apices that extend toward and may or may not reach the airway surface (Figs. 1, 2 and 3).

In human, the subepithelial tissue can be subdivided into a lamina propria, situated between the basement membrane and the muscularis mucosa, and a submucosa, consisting of all the remaining airway tissue (Fraser) while, Gartner \& Hiatt mentioned the wall of trachea and bronchi divided into mucosa, submucosa and adventitia. The lamina propria consists principally of a network of capillaries, a meshwork of connective tissue fibers continuous with the basement membrane (Figs. 1, 2). Stevens \& Lowe (1992) observed that the lamina propria in human contain mucus and seromucus glands with ducts open onto the epithelial surface but we did not showed these mucosal glands in the examined red foxes. The submucosa formed of connective tissue elements and blood vessels and devoid of tracheobronchial glands in red fox (Figs. 1 and 2) meanwhile (Fraser; Lesson et al., 1988) in human record the submucoal mucus and seromucus gland in trachea and principle bronchi.

The findings in current study cleared that the adventitia contain tracheal cartilage and muscle in trachea and bronchial cartilages and muscles inbronchi. Tracheal muscle is transverse bundles and attached to the outer perichondrium (Figs. 1 and 2). In the studied red foxes, muscles of bronchi were organized in transverse bundles close to the epithelium adjacent to the lamina propria (lamina mucularis mucosa) and longitudinal bundles close to the cartilages (Figs. 1 and 2). These results were in accordance to Fraser in human. 


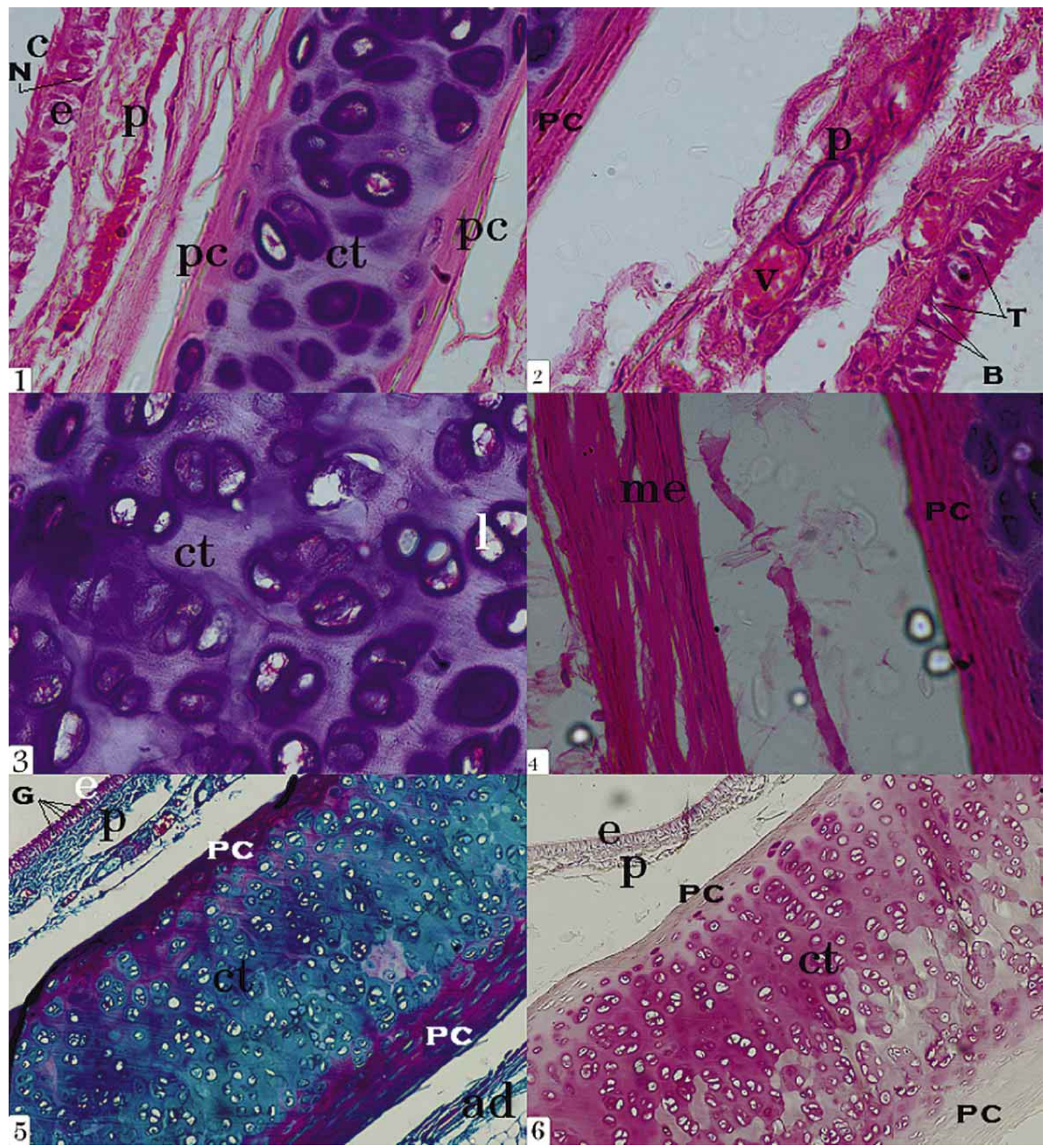

Fig. 1. Photomicrograph of the trachea of red fox: Cartilartilagines tracheales (ct), musculus trachealis (m), Lamina propria (p), epithelium (e), perichondrium (pc), adventitia (ad), goblet cells $(\mathrm{G})$, blood vessel (v), tall columnar cells $(\mathrm{T})$, basal cells (B), cilia (C), neuroendocrine cells $(\mathrm{N})$.

Alveoli in the examined specimens were demarcated by septa composed of a continuous layer of epithelial cells overlying a thin interstitium (Fig. 3). The layer of epithelial cells consists principally of type I and type II pneumocytes; alveolar macrophages are also present on the epithelial surface. The interstitium contains 


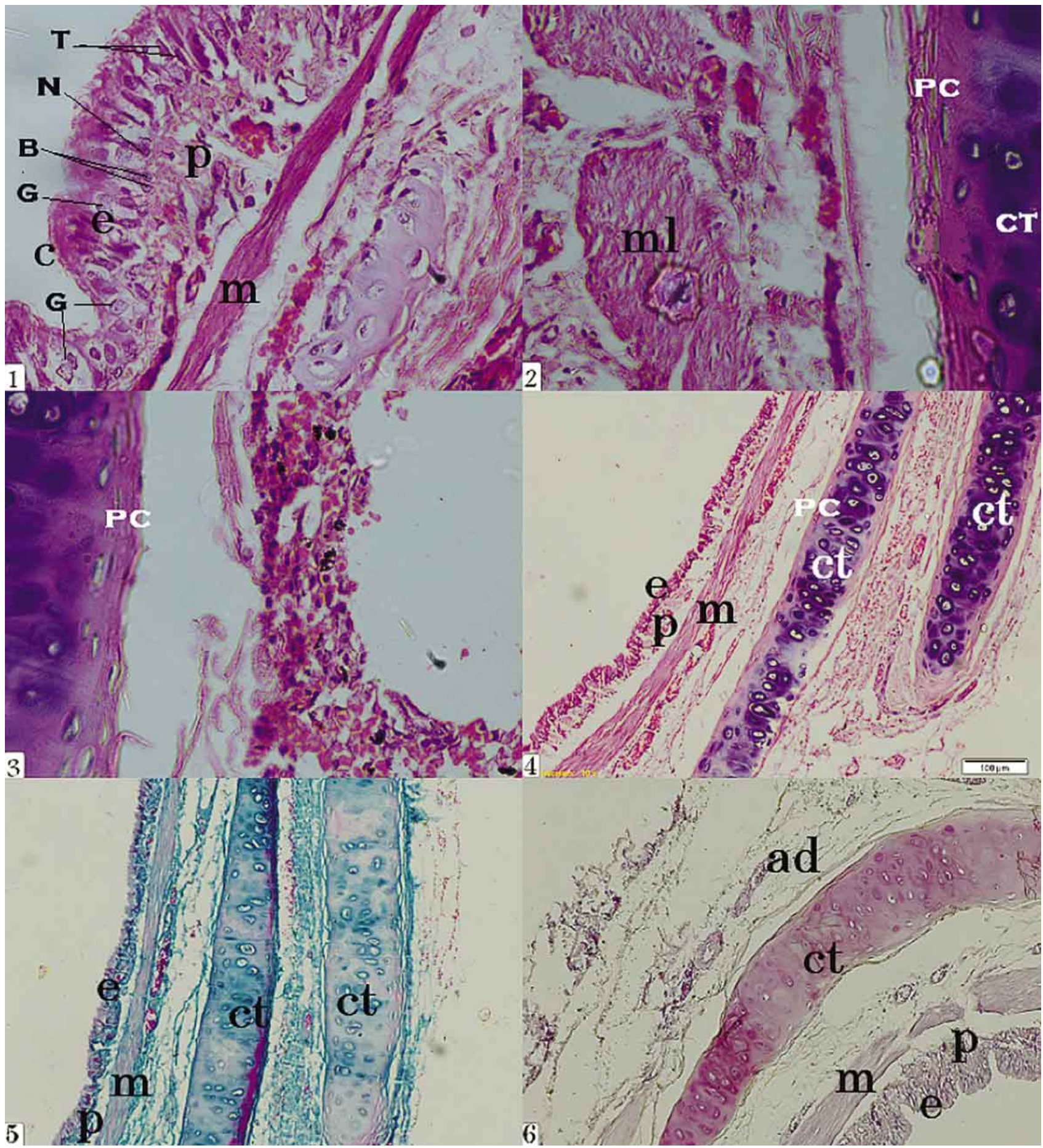

Fig. 2. Photomicrograph of the principle bronchus of red fox: Cartilartilagines broncheales (ct), lamina muscularis mucosa (m), Lamina propria (p), epithelium (e), perichondrium (pc), adventitia (ad), goblet cells (g), blood vessel (v), tall columnar cells (t), basal cells (b), cilia (c), neuroendocrine cells $(\mathrm{N})$, longitudinal smooth muscle $(\mathrm{ml})$.

capillaries involved in gas exchange, as well as connective tissue and a variety of cells responsible for maintaining alveolar shape and defense (Fig. 3).
Type I alveolar cells cover approximately $95 \%$ of the alveolar septal surface. The nucleus of this cell type is small and covered by a thin rim of cytoplasm containing few 


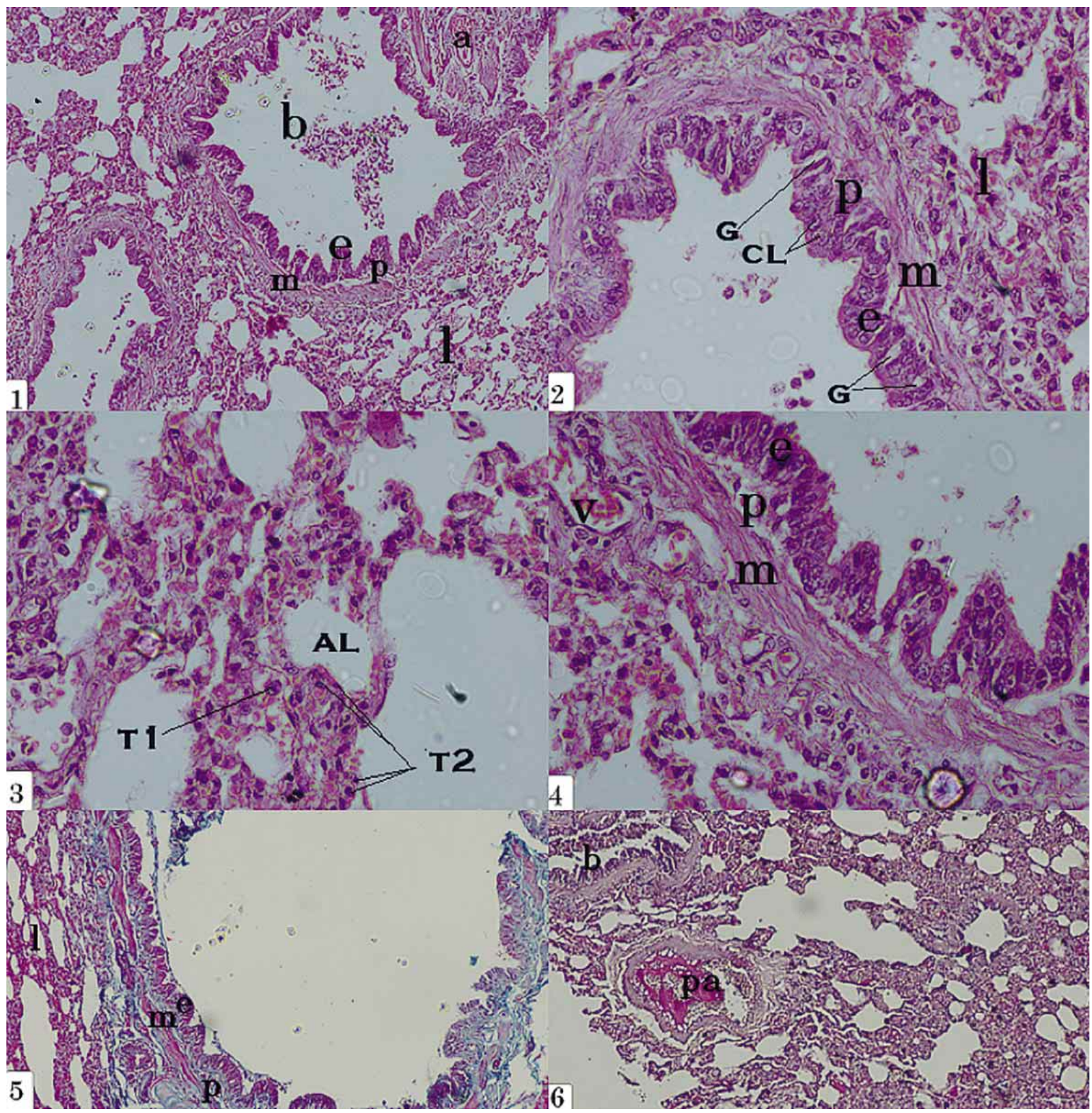

Fig. 3. Photomicrograph of the lung of red fox: membranous bronchiol (b), lamina muscularis mucosa (m), Lamina propria (p), epithelium (e), adventitia (ad), goblet cells (g), blood vessel (v), lung tissue (L), clara cells (exocrine bronchiolar cells) (cl), pulmonary artery branch (pa), alveolar cell type I (T2), alveolar cell type II (T1).

organelles. The rest of the cytoplasm extends as a broad Type I alveolar cells cover approximately $95 \%$ of the alveolar septal surface (Fig. 3). The nucleus of this cell type is small and covered by a thin rim of cytoplasm containing few organelles (Fig. 3). Gartner \& Hiatt, Fraser and Lesson et $a l$. reported that the shape of pneumocyte type I in human is squamus. Type II epithelial cells tend to be located near corners where alveoli meet. Their cytoplasm is prominent (Fig. 1). They were large cuboidal in shape in the same line with that reported by Gartner \& Hiatt in human. Fraser in human recorded that the Type II epithelial cells is the source of surfactant, the substance responsible for modifying alveolar surface tension. Type II cells have a number of other important functions. A small number are mitotically active 

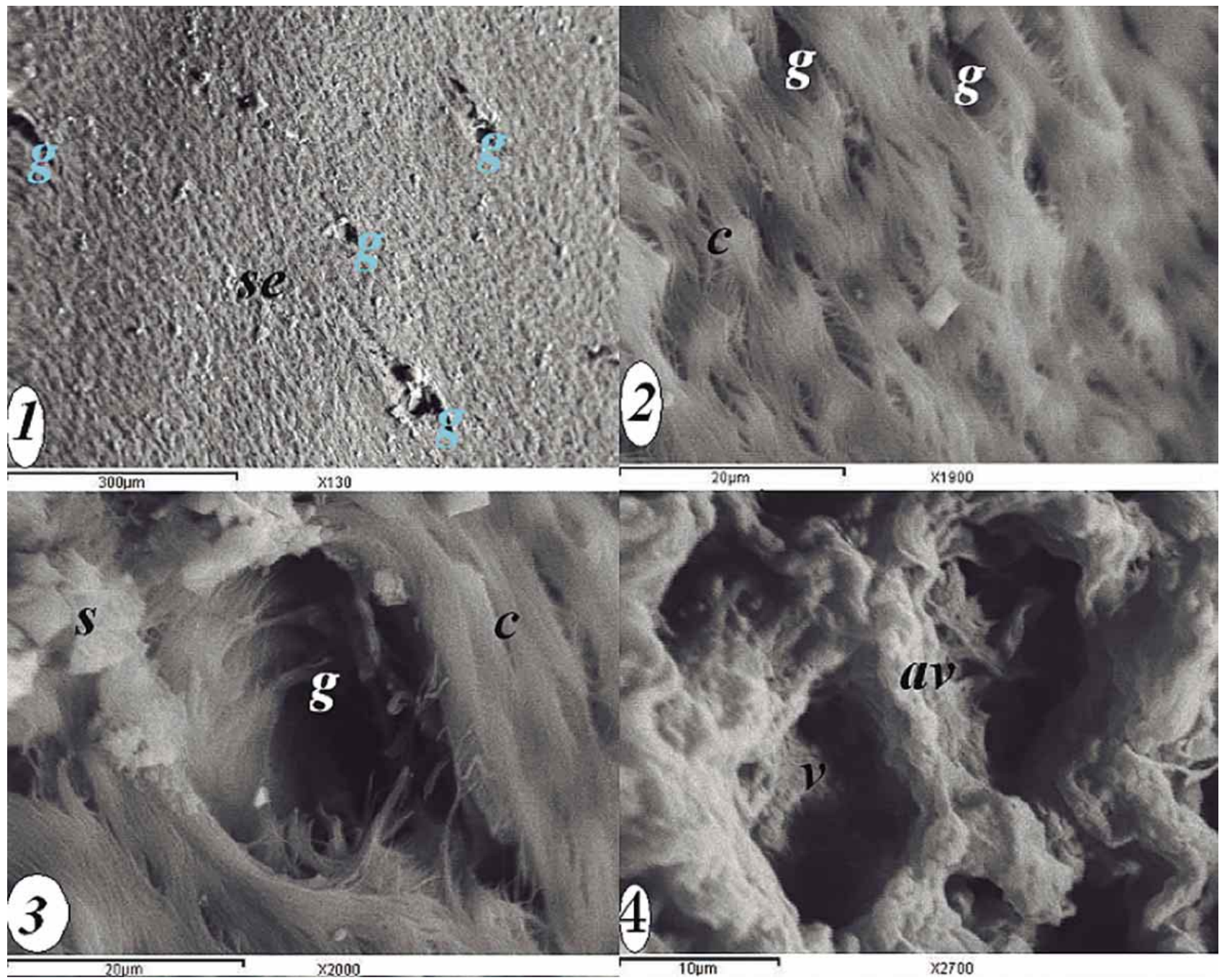

Fig. 4. Scanning electron microscopy of the trachea and bronchi (1, 2 and3) and lung (4) of red fox: cilia (c), goblet cell orifices (g), mucous secretion (s), alveoli (v), alveolar cells (av), luminal surface (se).

and are able to differentiate into type I cells, repopulating the alveolar surface as the latter die.

The bronchioles were seen lined by simple cuboidal to columnar without cilia (Fig. 3) as similar to that showed by Corkmack \& Ham and Fawcett in human.

SEM studies. The mucosal surface of both trachea and bronchi of examined specimens was completely covered by cilia (Fig. 4) similar to that present in cattle (Kahwa \& Purton, 1996; Iovannitti et al., 1985), and neonatal kids (Kahwa et al., 2000). Moreover, in newborn puppies the dorsal wall only is ciliated while the lateral and ventral wall only has patches of cilia in camel (Raji \& Naserpour, 2007; Wright et al., 1983). In this study, the largest area of the investigated tissue surfaces showed nothing but a regular array of cilia obscuring cell surfaces (Fig. 4). Cilia were relatively large cylindrical structures and they were interposed between the scanning beam and the cell surfaces. Goblet cells were sparse. There were few glandular openings or goblet cells (Fig. 4). Also we observe the mucous secretion of the goblet cells cover the cilia, it might be called the viscoelastic layer (Fig. 4) as reported by Raji \& Naserpour in camel and Cross \& Mercer (1993) in human and the later exceeded that the cilia showed undulating movement under this layer. Raji \& Naserpour, in camel reported that layer composed of glycoprotein and mucin secreted by goblet cells and mucosal cells of the submucosal gland. Moreover Kahwa et al. and Kanda \& Hilding (1968) resulted that the density of the cilia in kids less than that in adult in the goat. Rhodin \& Dalhamn (1956) and Rhodin (1963) in human established that the epithelial covering is made up of four cell types: ciliated, goblet, brush, and 'basal' cells. They added that the intermediate cells were described similar to, but not identical with, the above four, and it was stated that 
the tracheal and principal bronchial surfaces were uniform. Microvillous cells discussed above were referred to that found by Alexander et al. as 'collicular'. A similar cell type was termed 'nonciliated' by Hansell \& Moretti (1969) in their transmission electron microscopic description of the mouse trachea.

The few glandular openings we found might be related to the large number of secretory granules of variable electron densities seen in every cell of the tissues examined (Fig. 4). It is interesting in this regard to compare the similar composition of the apical granules of the microvillous cells found in the tracheobronchial surfaces in the rat (Fig. 4) and the ones seen by Meyrick \& Reid (1970) in human bronchial glandular tissue, which may account for the scarcity of these glands in the rat, similar granules being discharged from surface cells.

MOUSSA, E. A. \& HASSAN, S. A. Histología y microscopía electrónica de barrido de las vías respiratorias inferiores en el zorro rojo adulto (Vulpes vulpes). Int. J. Morphol., 33(1):267-274, 2015.

RESUMEN: El estudio se realizó en tres zorros rojos adultos sanos, recién fallecidos, de ambos sexos, con un peso aproximado 4,6 kg recogidos de Abou Rawwash, Giza, Egipto. La pared de la tráquea y los bronquios estaban formados por mucosa, submucosa y adventicia. La mucosa estaba formada por un epitelio estratificado y lámina propia. El epitelio respiratorio ciliado compuesto de células caliciformes, células basales y células neuroendocrinas. Las células calciformes representaban alrededor del 20 al $30 \%$ de las células más proximales. Las células basales eran células triangulares relativamente pequeñas cuyas bases están unidas a la membrana basal. El bronquiolo principal está cubierto por un epitelio columnar simple no ciliado que contiene algunas células exocrinas bronquiolares y células caliciformes. Las células neuroendocrinas constituyen aproximadamente 4 a $5 \%$ de las células epiteliales bronquiales, unidas en sus bases a la membrana basal y tienen ápices de ahusamiento. La lámina propia consiste principalmente en una red de capilares, una malla de fibras de tejido conectivo continuo con la membrana basal. La submucosa formada por elementos del tejido conectivo y vasos sanguíneos y escasas glándulas traqueobronquiales. La capa adventicia contiene cartílago traqueal y muscular en la tráquea, y los bronquios cartílagos y músculos. En los bronquios, el músculo está compuesto de haces transversales cercanos al epitelio próximo a la lámina propia y haces longitudinales cerca de los cartílagos. Los alvéolos están delimitados por tabiques compuestos de una capa continua de células epiteliales que recubren un intersticio delgado. Las células epiteliales se componen principalmente de neumocitos tipo I y tipo II. El MEB reveló que la superficie de la mucosa de la tráquea y los bronquios estaba completamente cubierta por cilios. Se observaron pocas aberturas glandulares o células caliciformes.

PALABRAS CLAVE: Barrido; Zorro; Respiratorio; Histología.

\section{REFERENCES}

Alexander, I. G.; Ritchie, B. C. \& Maloney, J. E. Scanning electron microscopy of respiratory tissues in the rat. J. Anat., 110(Pt. 3):491-2, 1971.

Basuony, M. I.; Saleh, M. A.; Riad, A. \& Fathy, W. Food composition and feeding ecology of the Red Fox Vulpes vulpes (Linnaeus, 1758) in Egypt. Egypt. J. Biol., 7:96-102, 2005.

Blenkinsopp, W. K. Proliferation of respiratory tract epithelium in the rat. Exp. Cell Res., 46(1):144-54, 1967.

Corkmack, D. H. \& Ham, A. W. Ham's Histology. 9th ed. Philadelphia, Lippincott Williams \& Wilkins, 1989. pp.54166.

Cross, P. C. \& Mercer, K. L. Cell and Ultrastructure. New York, W. H. Freeman and Company, 1993. pp.304-16.

Dellmann, H. D. \& Eurell, J. A. Textbook of Veterinary Histology. 5th ed. Baltimore, Lippincott, Williams \& Wilkins, 1998.

Fawcett, D. W. Textbook of Histology. 5th ed. New York, Chapman \& Tall, 1994. pp.704-24.
Fedriani, J. M.; Fuller, T. K.; Sauvajot, R. M. \& York, E. C. Competition and intraguild predation among three sympatric carnivores. Oecologia, 125(2):258-70, 2000.

Fraser, R. S. Histology and Gross Anatomy of the Respiratory Tract. In: Hamid, Q.; Shannon, J. \& Martin, J. (Eds.). Physiologic Basis of Respiratory Disease. Hamilton (ON), B.C. Decker Inc., 2005. pp.1-14

Gartner, L. P. \& Hiatt, L. V. Color Textbook of Histology. 3rd ed. Ann Arbor, W. B. Saunders Co., 2007. pp.345-65.

Hansell, M. M. \& Moretti, R. L. Ultrastructure of the mouse tracheal epithelium. J. Morphol., 128(2):159-69, 1969.

International Committee of Veterinary Gross Anatomical Nomenclature (I. C. V. G. A. N.). Nomina Anatomica Veterinaria. 5th ed. Columbia, Editorial Committee, 2012. pp.5277.

Iovannitti, B.; Pirie, H. M. \& Wright, N. G. Scanning electron microscopic study of the lower respiratory tract in calves and adult cattle. Res. Vet. Sci., 38(1):80-7, 1985. 
MOUSSA, E. A. \& HASSAN, S. A. Histology and scanning electron microscopy of the lower respiratory tract in the adult red fox (Vulpes vulpes). Int. J. Morphol., 33(1):267-274, 2015.

Kahwa, C. K.; Balemba, O. B. \& Assey, R. J. The pattern of ciliation and the development of the epithelial lining of the respiratory tract in the neonatal kid: a scanning electron microscopic study. Small Rumin. Res., 37(1-2):27-34, 2000.

Kahwa, C. K. B. \& Purton, M. Histological and histochemical study of epithelial lining of the respiratory tract in adult goats. Small Rumin. Res., 20(2):181-6, 1996.

Kanda, T. \& Hilding, D. Development of respiratory tract cilia in fetal rabbits. Electron microscopic investigation. Acta Otolaryngol., 65(6):611-24, 1968.

Lesson, T. S.; Lesson, C. R. \& Paparo, A. A. Textbook/Atlas of Histology. Philadelphia, W. B. Saunders Co., 1988. pp.30555 .

Meyrick, B. \& Reid, L. Ultrastructure of cells in the human bronchial submucosal glands. J. Anat., 107(Pt. 2):281-99, 1970.

National Institutes of Health (NIH). Guide for the Care and Use of Laboratory Animals. Bethesda, National Institutes of Health Publication No. 85-23, 1996.

Raji, A. R. \& Naserpour, M. Light and electron microscopic studies of the trachea in the one-humped camel (Camelus dromedarius). Anat. Histol. Embryol., 36(1):10-3, 2007.

Reilly, J. S. Euthanasia of animals used for scientific purposes. Adelaide, Australian and New Zealand Council for the Care of Animals in Research and Teaching, 1993.

Rhodin, J. A. \& Dalhamn, T. Electron microscopy of the tracheal ciliated mucosa in rat. Z. Zellforsch. Mikrosk. Anat., 44(4):345412, 1956.

Rhodin, J. A. An Atlas of Ultrastructure. Philadelphia, W. B. Saunders, 1963.

Stevens, A. \& Lowe, J. S. Histology. London, Gower Medical Publishing, 1992.

Wright, N. G.; Brown, R. M.; McCandlish, I. A.; Thompson, H. \& Cornwell, H. J. Patterns of cilia formation in the lower respiratory tract of the dog: a scanning electron microscopic study. Res. Vet. Sci., 34(3):340-6, 1983.

\author{
Correspondence to: \\ Said Hassan \\ Department of Anatomy and Embryology \\ Faculty of Veterinary Medicine \\ Suez Canal University \\ Ismailia \\ EGYPT
}

Email: shassan1978@gmail.com

Received: 27-09-2014

Accepted: 02-01-2015 